\title{
Isolated levocardia with situs inversus without cardiac abnormality in fetus: prenatal diagnosis and management
}

\author{
Mucize Eriç Özdemir (D), Oya Demirci \\ Department of Perinatology, Zeynep Kamil Maternity and Children's Diseases Training and Research Hospital., Health Sciences University, Istanbul, Turkey
}

\begin{abstract}
Objective: Isolated levocardia is a situs abnormality that the heart is in the normal levo position, but the abdominal viscera are in dextro position. Most cases are accompanied by structural heart anomalies. In this case, we aimed to present a fetus with isolated levocardia without cardiac abnormality.

Case: The mother was referred to our clinic with a suspicion of fetal dextrocardia at 22 weeks of gestation. When detailed examination was planned by ultrasonography isolated levocardia was detected in fetus. There were no cardiac abnormalities in fetal echocardiography. Fetus was followed up until delivery and newborn was examined again at postnatal period. No problem was detected until the age of 2 years.

Conclusion: Fetal situs should be assessed by ultrasonography in all pregnant women.
\end{abstract}

Keywords: Fetus, levocardia, ultrasonography.

\section{Introduction}

Isolated levocardia (IL) is a kind of situs anomaly that the heart is in the normal levo position, but the abdominal viscera are in dextro position. ${ }^{[1]}$ The vast majority of the cases have major cardiac anomalies. ${ }^{[2]}$ This condition is rare when it is associated with a normal cardiac structure $^{[3]}$ and the incidence of this anomaly in fetuses is not known. ${ }^{[1]}$ Most of IL patients who do not have cardiac and intestinal abnormalities survive with unknown reasons. So, the prenatal incidence of IL is difficult to esti-

\section{Özet: Kardiyak anomalisi olmayan fetüste situs inversuslu izole levokardi: Prenatal tanı ve yönetim}

Amaç: İzole levokardi, kalbin normal levo pozisyonunda olduğu fakat abdominal iç organların dekstro pozisyonunda olduğu bir situs anomalisidir. Çoğu olguda yapısal kalp anomalileri de eşlik etmektedir. Çalışmamızda, kardiyak anomalisi olmayan izole levokardili bir fetüsü sunmayı amaçladık.

Olgu: Olgumuz, 22. gebelik haftasında fetal dekstrokardi şüphesiyle kliniğimize sevk edildi. Planlanan detaylı ultrason muayenesinde, fetüste izole levokardi tespit edildi. Fetal ekokardiyografide hiçbir kardiyak anomali görülmedi. Fetüs doğuma kadar takip edildi ve yenidoğan, postnatal dönemde yeniden muayene edildi. 2 yaşına kadar hiçbir sorun tespit edilmedi.

Sonuç: Fetal situs tüm gebelerde ultrasonografi muayenesi ile değerlendirilmelidir.

Anahtar sözcükler: Fetüs, levokardi, ultrasonografi.

mate. ${ }^{[4]}$ According to reports, the incidence of IL is approximately 1 per 22,000 births, ${ }^{[5]}$ and it represents $0.4-1.2 \%$ of all congenital heart disease (CHD) ${ }^{[6]}$ In this study, we reported a case of IL with structurally normal heart and no rhythm abnormalities.

\section{Case Report}

A 28-year-old woman gravida 3 para 2 with no family history of congenital anomalies, having consanguineous marriage and a normal medical history had routine pre-

\footnotetext{
Correspondence: Mucize Eriç Özdemir, MD. Department of Perinatology, Zeynep Kamil Maternity and Children's Diseases Training and Research Hospital., Health Sciences University, Istanbul, Turkey. e-mail: ozdemir.mucize@gmail.com / Received: January 15, 2020; Accepted: February 17, 2020 Please cite this article as: Eriç Özdemir M, Demirci O. Isolated levocardia with situs inversus without cardiac abnormality in fetus: prenatal diagnosis and management. Perinatal Journal 2020;28(1):48-51. doi:10.2399/prn.20.0281004
} 
natal ultrasound with suspicion of dextrocardia. The patient rejected to have any of aneuploidy screening tests. The patient was referred for fetal echocardiography at 22 weeks of gestation. On ultrasound, the fetus had a leftsided heart and a right-sided stomach (Fig. 1). The gallbladder was located at right side to the umbilical vein in the midline. Fetal echocardiography showed situs solitus of the atria, the ventricles, and the main arteries. The inferior vena cava (VCI) and aorta were both on the left, and the main portal vein was on the right side. The VCI was running on the left side, and returning to the anterior right side of the diaphragm (Fig. 2). Portal venous structures and ductus venosus were normal. Sonographic evaluation of the fetus revealed no additional abnormalities. With these findings, the case was considered as IL. Amniocentesis showed normal male karyotype. At 38 weeks of gestation, a planned cesarean section was performed secondary to fetal macrosomia. A male infant was born with a birth weight of $4100 \mathrm{~g}$ and an Apgar score of 9 at $1 \mathrm{~min}$ and 8 at $5 \mathrm{~min}$. The neonate's electrocardiogram showed normal sinus rhythm and postnatal echocardiography confirmed the prenatal diagnosis. Abdominal ultrasonography of the baby after birth revealed right-sided spleen and stomach and confirmed left-sided VCI. The baby was in good condition and oral feeding was started. The boy was stable and discharged home after a week. He was regularly followed up by a pediatrician and there were no major problems recorded with his health at 2 years.

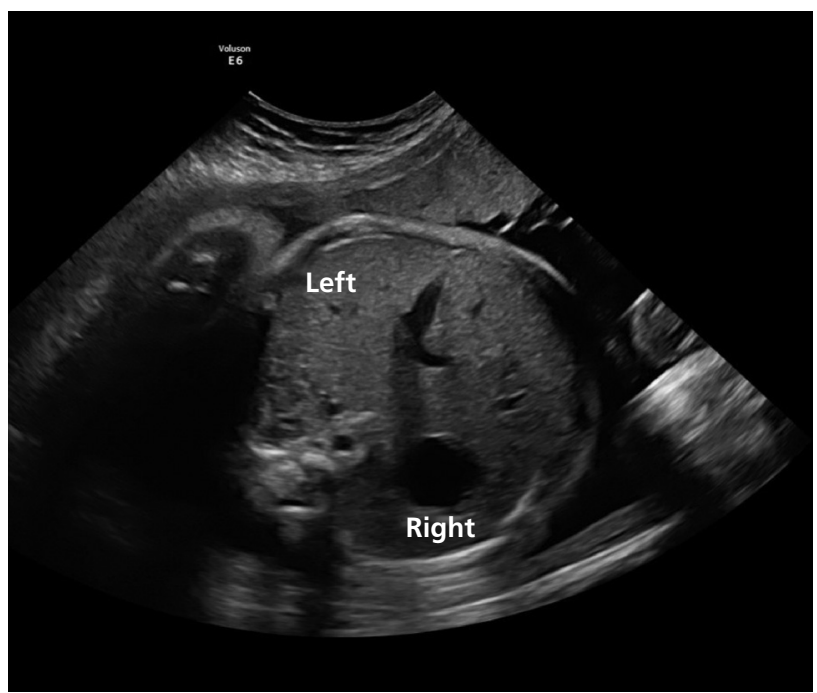

Fig. 1. A right-sided stomach of the case with left-sided heart case is shown on ultrasound image.

\section{Discussion}

The fetal side and axis must be examined carefully for diagnosis of cardiac malpositions. Özkutlu et al. suggested that Cordes technique provides a simple determination of the fetal situs. ${ }^{[7]}$ Situs anomalies are the least common forms of CHD. ${ }^{[8]}$ 'Situs' defines the arrangement of the viscera, atria, and vessels within the body. 'Situs solitus' refers to normal arrangement; 'situs inversus' refers to inverted arrangement; and 'situs ambiguus' (heterotaxy) refers to abnormalities in arrangements that can neither be described as solitus nor inversus. ${ }^{[9]}$ Univentricular physiology and transposition of the great arteries are more common in fetuses with levocardia, whereas abnormal pulmonary venous connection, double outlet of right ventricle and left ventricle outlet obstruction are more frequent in fetuses with dextrocardia. ${ }^{[10]} \mathrm{IL}$ is a subtype of situs inversus that was first defined by Taussing in $1947 .^{[11]}$ Then, Van Praagh et al ${ }^{[2]}$ classified this condition as a partial situs inversus in which the heart remains in levocardia. In $95 \%$ of the cases, major cardiac anomalies ${ }^{[2]}$ are detected and only $5-13 \%$ of the cases survive for longer than 5 years. ${ }^{[12,13]} \mathrm{IL}$ is one of the heterotaxy syndromes and should be carefully evaluated in terms of associated organ anomalies. Splenic abnormalities like asplenia and polysplenia are usually encountered with this anomaly. ${ }^{[2]}$ Vaccination against Streptococcus pneumoniae and Neisseria meningitidis and daily antibiotic prophylax-

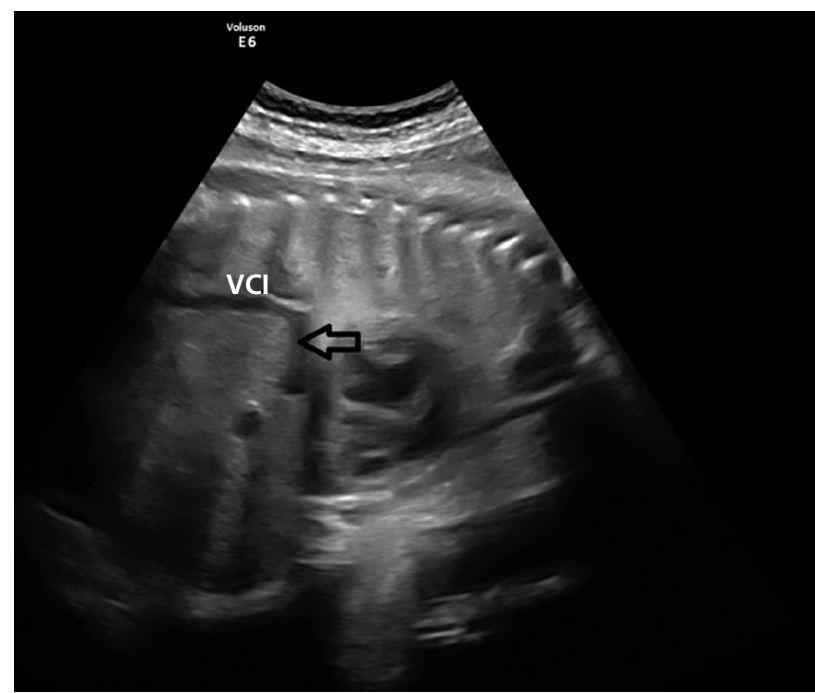

Fig. 2. The vena cava inferior $(\mathrm{VCl})$ returns to the anterior right side of the diaphragm. 
is can be suggested for asplenic patients to prevent serious infection. ${ }^{[9]}$ In some cases, IL may be complicated by an intestinal malrotation and intestinal obstruction due to peritoneal band, intraluminal web and an aberrant vessel, commonly the superior mesenteric artery. These cases cannot be detected for years until an abdominal surgery. ${ }^{[1,15]}$ Interrupted VCI with azygous continuation can be detected in cases of IL. ${ }^{[16]}$ and intestinal malrotation is generally related to interrupted VCI. ${ }^{[3]}$ Also, double inferior vena cava (DVCI) has been reported in some IL cases. DVCI may be important for a retroperitoneal surgery and management of a thromboembolic disease. ${ }^{[17]}$ Rhythm abnormalities such as atrioventricular nodal reentry tachycardia and sick sinus syndrome are reported in cases of IL. Therefore, longterm monitorization is recommended for these patients against new-onset arrhythmias. ${ }^{[18]}$ Since there were no asplenia detected in our case, the neonatologist did not recommend vaccination and daily antibiotherapy. In the neonatal period there was no sign of primary ciliary dyskinesia and the change in respiratory sounds was associated with gastroesophageal reflux. Findings of intestinal malrotation and obstruction were not observed, there was no pathology associated with VCI. Cardiac arrhythmia did not develop during the neonatal period and subsequent follow-ups.

The pathogenesis of IL is not entirely clear but it is associated with the abnormalities in the embryological development process. Genetic studies do not define a specific gene mutation, but there are studies investigating the primer ciliary dyskinesia (PCD) gene. The lack of the PCD gene is thought to be resulting in IL when it is absent in the regions associated with the development of abdominal visceral organs. ${ }^{[4]}$ Heterotaxic syndromes are more common in diabetic pregnancies, first trimester cocaine use, and in those with family history of CHD. ${ }^{[19]}$ In our case there were no risk factors underlying IL. Prognosis of IL mostly depends on the severity of associated cardiac anomalies. ${ }^{[9]}$ In addition, intestinal malrotation and associated obstructions may be life-threatening, requiring immediate surgical intervention. $^{[4]}$ The IL patients with no CHD and no intestinal malrotation are considered healthy and may not be diagnosed until later ages. It is important to diagnose fetuses with IL prenatally. Although accompanying no cardiac anomalies, it is important to follow the neonate carefully for the complications like intestinal malrotation and bowel obstruction may develop during postna- tal period. Families with the baby prenatally diagnosed with IL syndrome can be better informed about the prognosis. In prenatally suspected cases, a more comprehensive examination can be performed with postnatal MR (magnetic resonance) imaging. MR provides more detailed information about the anatomy of the abdominal organs and provides a more detailed examination of bowel problems. ${ }^{[20]}$ Newborns with IL should be followed-up closely especially after feeding. The families of uncomplicated cases should be also warned in terms of gastrointestinal pathologies and cardiac arrhythmias that may develop in future. For the abdominal surgeries that may be encountered in the future, it is important to inform the surgical team about the anatomy in advance.

\section{Conclusion}

In the absence of associated cardiac anomaly and chromosomal abnormality, IL cases have low risk for morbidity and mortality. Anatomical investigation and careful observation may improve the outcome of IL.

Conflicts of Interest: No conflicts declared

\section{References}

1. Gindes L, Hegesh J, Barkai G, Jacobson JM, Achiron R. Isolated levocardia: prenatal diagnosis, clinical importance, and literature review. J Ultrasound Med 2007;26:361-5.

2. Van Praagh S, Santini F, Sanders SP. Cardiac malpositions with special emphasis on visceral heterotaxy (asplenia and polysplenia syndromes). In: Fyler DC, editor. Nadas' pediatric cardiology. Philadelphia, PA: Hanley \& Belfus; 1992. p. 589608.

3. Ghawi H, Zghouzi MM, Emahbes TM, Avad SM. Prenatal diagnosis of isolated levocardia and a structurally normal heart: two case reports and a review of the literature. Pediatric Cardiol 2013;34:1034-7.

4. Katsuya S, Yamada S, Ukita M, Nishimura H, Matsumura N, Fukuhara K, et al. Isolated levocardia: prenatal diagnosis and management. Congenit Anom (Kyoto) 2009;49:56-60.

5. Campbell M, Deuchar DC. Dextrocardia and isolated laevocardia. I. Isolated laevocardia. Br Heart J 1965;27:69-82.

6. Liberthson RR, Hastreiter AR, Sinha SN, Bharati S, Novak GM, Lev M. Levocardia with visceral heterotaxy - isolated levocardia: pathologic anatomy and its clinical implications. Am Heart J 1973;85:40-54.

7. Ozkutlu S, Bostan OM, Deren O, Onderoglu L, Kale G, Gucer S, et al. Prenatal echocardiographic diagnosis of cardiac right/left axis and malpositions according to standardized Cordes technique. Anadolu Kardiyol Derg 2011;11:131-6. 
8. Lin AE, Krikov S, Riehle-Colarusso T, Frias JL, Belmont J, Anderka M, et al.; National Birth Defects Prevention Study. Laterality defects in the national birth defects prevention study (1998-2007): birth prevalence and descriptive epidemiology. Am J Med Genet A 2014;164A:2581-91.

9. Lambert TE, Kuller J, Small M, Rhee E, Barker P. Abnormalities of fetal situs: an overview and literature review. Obstet Gynecol Surv 2016;71:33-8.

10. Wang X, Shi Y, Zeng S, Zhou J, Zhou J, Yuan H, et al. Comparing levocardia and dextrocardia in fetuses with heterotaxy syndrome: prenatal features, clinical significance and outcomes. BMC Pregnancy Childbirth 2017;17:393.

11. Taussig HB. Congenital malformation of the heart. New York, NY: Commonwealth Fund; 1947.

12. Annamalai AL, Ramakrishnan T. Levocardia with partial subdiaphragmatic heterotaxia. Indian Heart J 1967;19:268-74.

13. Harris TR, Rainey RL. Ideal isolated levocardia. Am Heart J $1965 ; 70: 440-8$.

14. Budhiraja S, Singh G, Miglani HP, Mitra SK. Neonatal intestinal obstruction with isolated levocardia. J Pediatr Surg 2000; 35:1115-6.
15. Tryfonas GI, Chaidos C, Avtzoglou PP, Zioutis J, Klokaris A, Papanastasopoulos A. Partial situs inversus: duodenal obstruction in a neonate with isolated levocardia. J Pediatr Surg 1992; 27:1584-6.

16. Altın H, Alp H, Karataş Z, Şap F, Baysal T, Karaslan S. Isolated levocardia, a rare situs anomaly: report of different two patients. Türkiye Klinikleri Cardiovascular Sciences 2013; 25:118-22.

17. $\mathrm{Ng}$ W', $\mathrm{Ng}$ SS. Double inferior vena cava: a report of three cases. Singapore Med J 2009;50:e211-3.

18. Alberto Lopez J, Angelini P, Lufschanowski R. Successful ablation of atrioventricular node reentry tachycardia in a patient with crisscross heart and situs inversus levocardia. J Interv Card Electrophysiol 2006;17:133-7.

19. Belmont JW, Mohapatra B, Towbin JA, Ware SM. Molecular genetics of heterotaxy syndromes. Curr Opin Cardiol 2004;19: 216-20.

20. Nemec SF, Brugger PC, Nemec U, Bettelheim D, Kasprian G, Amann G, et al. Situs anomalies on prenatal MRI. Eur J Radiol 2012;81:e495-501.

Bu makalenin kullanım izni Creative Commons Attribution-NoCommercial-NoDerivs 3.0 Unported (CC BY-NC-ND3.0) lisansı aracılı̆̆ılya bedelsiz sunulmaktadır. / This work is licensed under the Creative Commons Attribution-NonCommercial-NoDerivs 3.0 Unported (CC BY-NC-ND3.0) License. To view a copy of this license, visit http://creativecommons.org/licenses/by-nc-nd/3.0/ or send a letter to Creative Commons, PO Box 1866, Mountain View, CA 94042, USA. 